2Rp4 アルギン酸ゲルの紹子情造に及ばすWG、金属イオンの影散

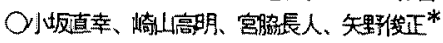
(查大·農化、*現䅦国大・物筫工) [目的]アルギン酸ゲルの安定性には、構成粘比 $(M / G)$ や午ル化に用い る金属イオンが関与することが知られているが、同時にそれらは絥し 瑇造にも影響を与える可能性がある。本研究では、WGや金属イオン

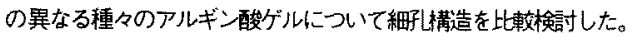

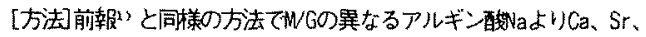
Baゲルビーズを調製し、ポりエチレングリコール(PEG)を用いた溶質

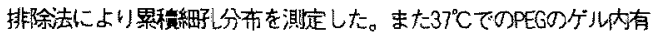
効拡散俨数をバッチ法により敗定し、屆曲任数を求めた。

[結果]Ca、Srゲルの場合、MG=2、4の細孔体積曲線は6nm付近で急激に 減少し10nn以上ではほぼ0となったが、MG=1.3、0.53の細子し体䅡曲線 は縓やかに隇少し、より細孔径の大きなゲルが㝵ら九た。一方、WG 1.3、0.53の場合、金属イオンを变えでも細孔体榬曲線には大きな差

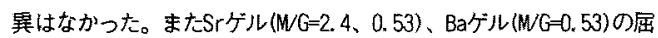

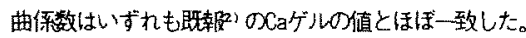

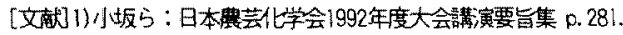

2)樋田5：日本㖘芸化学会1991年度大会譵演要旨集 p. 258 .

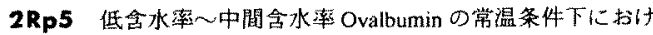
る加生によるダル状物質形成

(九大·食化工) O林 信行、早泪功、藤尾婎策

【目的】常温条件下での加王によるタンバク質のゲル状物算 形成举動を Ovalbumin 用いて調べた。【方法】含水率 $8.5 \sim$ $70 \%$ d.b. $(8 \sim 41 \%$ w.b.) に調湿した Ovalbumin (粗䌘：十力 ライテスク约）に対して 20 分間の加区好理（30 ${ }^{\circ} \mathrm{C} 、 10 \sim 50$ $\mathrm{MPa}$ )を行い、得られな試料伅ついて破壊強度湘定、DSC 及 ひ NMR 上る水の状態測定、SEM 隹察、SDS-PAGEと溶解度湘 定を行った。【結果】含水等 $20 \sim 40 \%$ Ovalbumin は $30^{\circ} \mathrm{C}$ の温度条件下で王力の作用で透明な堅いダル状物質を形成し たが、前後の水分含量ではゲル状物澌の形成は認められなか

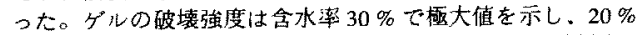

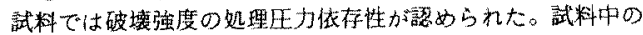
水の状惎、電気泳勳パターン、溶解度には変化が認められな かったことから、50 MPa までの圧力ではタンパタ質の変性は 生していないと考えられた。従って、加玨によるゲル状物質 の形成は水を介した分子相互の压着に上るものと推定された。 SEM観察の結果、陚料粒子が在力の作用て厈樎破壊され、王 着した状態になる様子が確認された。

\section{Rp6 ゾルーゲル車移点近傍の矮界兴動}

○藤井智幸，三浦 晋，熊谷 仁，宮脇長人，矢野伐正*

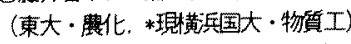

[緒言]ゾルーゲル転移点近傍では、梾々な物理量Aか転移点からの隔

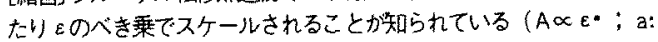

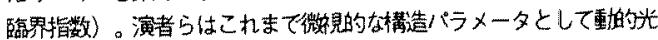
散乱法により求められる相関跑離(ゾルでは平均クラスター半径、ゲ

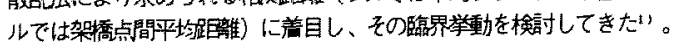
今回は、構造・物性相成の観点から、ソンルーゲル転移点近傍における

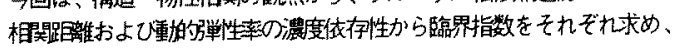
それらの關㐿について検討を加えた。

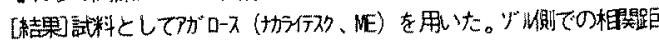

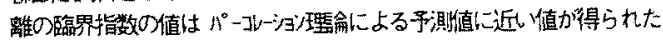

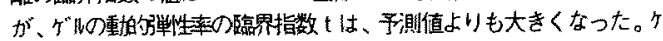

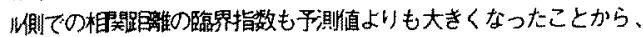

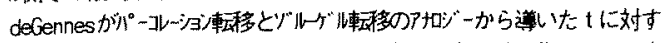

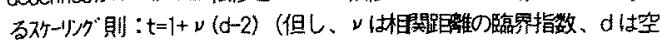
間次元)が成立していることが不势された。

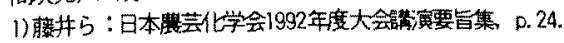

2Rp7ハイドロゲルの内部構造と分離機能们関する研究

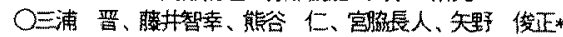
（東大·滕化、*現橫兵国大·物質工）

【目的】近年、生化学の分野でトド吹゙を用いた分離箱作の重要性が 增しつつある。本研究では、ゲ貯内内部棈造と分離機能との相関を明

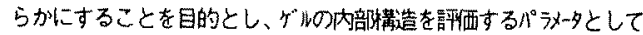

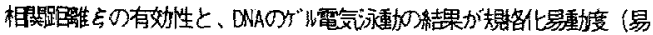

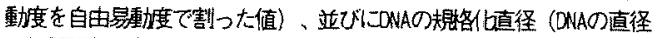
を相関距離で割つた俌)の二つのパラメータを用いて整理できる可能性と

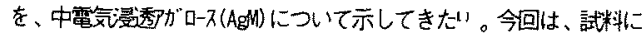
低電気浸㛢がロースを選定し、本解析去の一般性について検討した。

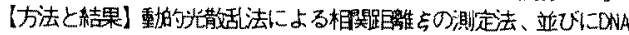

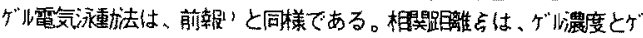

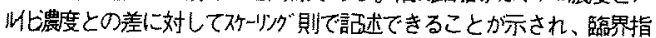
数は、A男の場合と同梯に理論值よりも大きな值か得られた。更に、

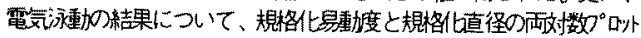

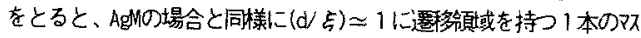
ターカーブで記术できることが示された。

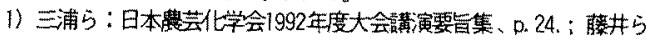
: 化学工学会第25回秋季大会講演要旨集、p. 182 (1992).

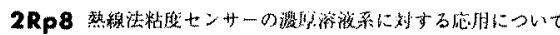

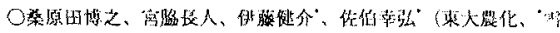

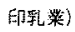

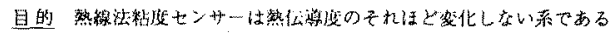

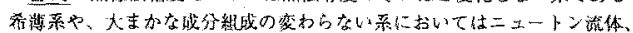

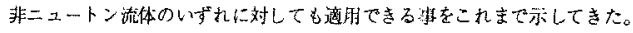

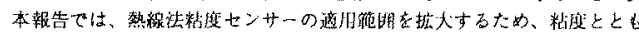

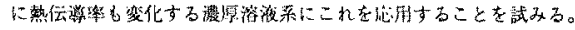

方法 陚料としてCMC（カルボキシメチルセルロース）・グルコー

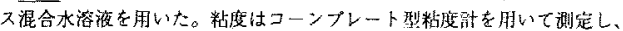

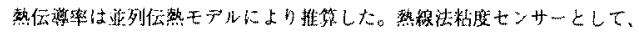

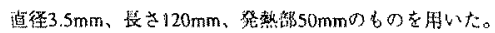

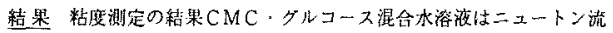
体としての取圾いが可能であった。この混合水溶液とダルコースを含まな

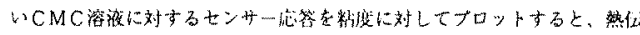

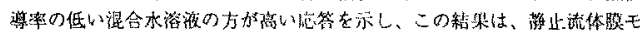
デルを用いた理諭式

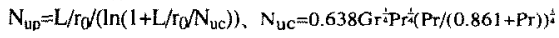

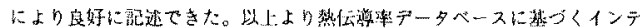

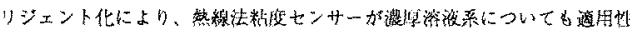
が㧨大できる叮能性が示された。

2RPQ リン酸カルシウム生成阻寒物監とカルシウムイオンの 相互作用

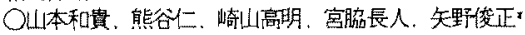
（東大·農化、現、横国大・物筫工)

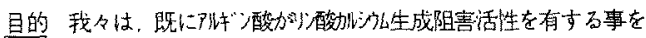

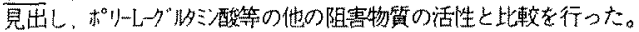

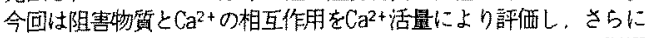

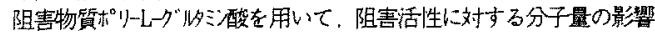
も検討した。

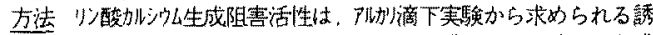

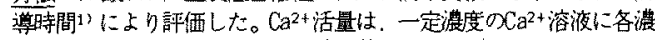
度の阻害物啠を添加し，加汸么選択電極により測定した。

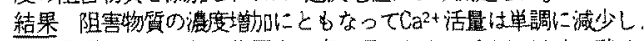

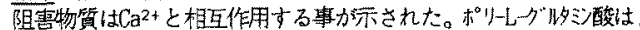

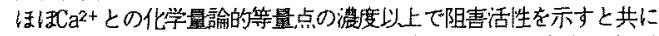

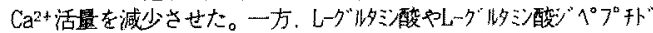

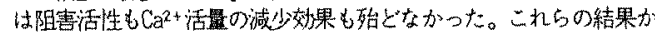
ら、阻害物質の活性発現にはCa す事が明らかとなり。更に求りしが㶤酒の活性発現に関しては一 定の分子量が迤要であることか沶㗎された。

1) K. Yananoto et al., Biosci. Biotech, Biochen, 56, 90-93(1992). 
2Rp $10 \kappa$-Carragenan-Chi tosan複合ゲルの荷電灯態に対する pHO影期○池田新矢、崎山高明、祝嘉鴻、宫脇長人

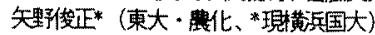

【目的】硫酸基を含む $\kappa$-Carragenanとアミノ基を含むChitosanか

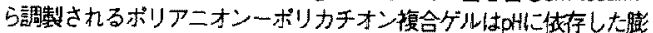

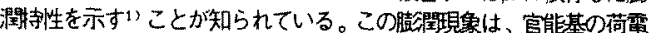

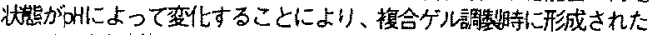
アニオン(硫䣼基)一カチオン(アミノ基)間の静電的結合が切断される ためと推臫される。本研究では、袙合ゲルの要位差敵を行い、ゲル 中に含まれる官能基の荷電忋態に対する中影翼について検討した。 【方法】 $\kappa$-Carragenan溶夜とChitosan溶液とを食塩の共存下で混 合し、生成した複合ゲルを遠し分離した。得られたゲルを水洗、乾臂

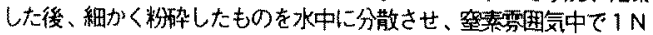

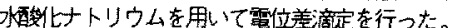

【結果】混合時の高分子濃度を各々0.1\%として調製した複合ゲルに

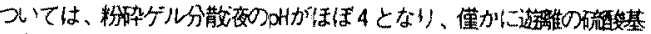
か存在することが和努された。また、滴定の絰果より、ゲル内からの

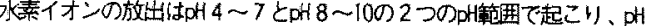
10においてゲル內の費電荷が最大に達することか明らかになった。

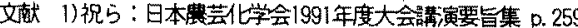

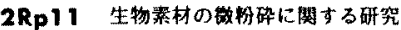
○早川功、藤尾雄策(九大.食化工! 山国良幸(日清製粉侏生産技術研究所)

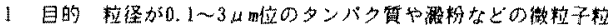
子は口睦内で脂肪と類以心刺激を与え、味賞改善效果を有すること か派告されてから、をれらを优替油脂としての応用することに期待

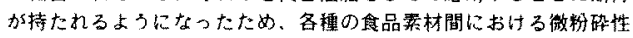
の踓易性やそ九机らの表面陳水性の変化などの解明を目的とする。

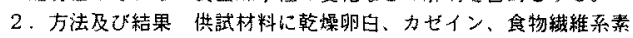
材として大豆揰皮を用い、日清エンジニャリンク製Curernt Jet (C」

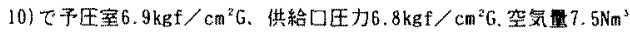
/minで微粉碟㣪、同社製Turbo Classifier (TC-15N)にて目的粒径

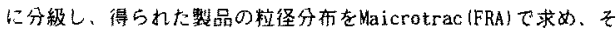

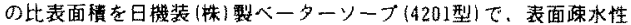

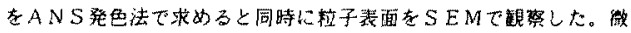

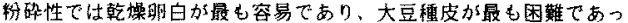
た。カゼインは商者の中間を示した。比表面棈法䏠径心必ずし依

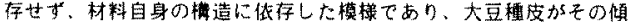

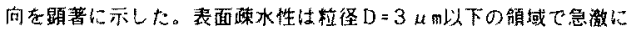
增大したか、大豆棰皮の䖝光强度は粒徍依存しなかった。

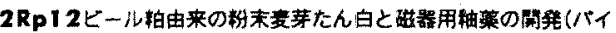 ロット・ブラント、式( 岸眼太郎(キリンビール・研㠰周発本部)}

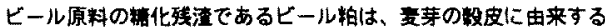

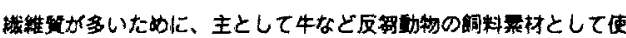
われてきた。そのビール柏の付加㬐值を高めて用途を広けるために、

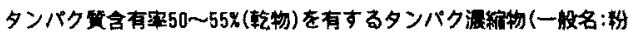

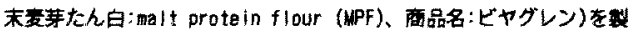

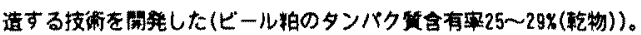
水分80\%弱のビール粕をロール・ミルに通すと、麦芽の经芽とタンバ

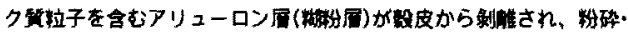

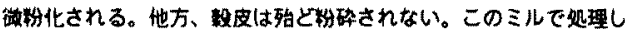

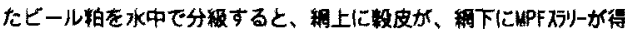

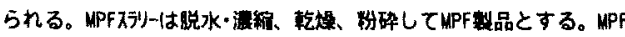

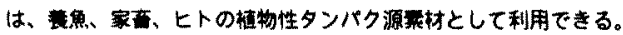

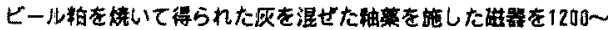

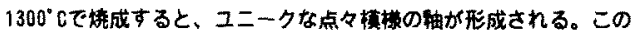
铀は、可に含まれるリン酯に电来すると考えられる。
2Rp1 3Thermal conductivity of frozen food materials and its relationship with state of water $o \mathrm{R}$. Pongsawatmanit, and O. Miyawaki (Dept. of Agric. Chem., The Univ. of Tokyo)

Objective: Thermal conductivity of trozen food is greatly affected by the change in water state, since the thermal conductivity of ice is about four times that of water. In this report, effective thermal conductivity of food sample was determined both in frozen and unfrozen states from the emperature range of -20 to $20^{\circ} \mathrm{C}$. The methods of ice fraction determination were also discussed. The effective thermal conductivity was analyzed through the structure model for heat conduction.

was analyzed through the structure model for heat conduction. Methods: The tood samples, gelatin gels and sucrose solutions, were prepared to determine the effective thermal conductivities with the coaxial concentric dual cylinders method under steady state condition. Craction was determined from the endothermic curve of phase change by DSC method as a function of temperature and compared with that calculated from phase diagram.

Results: The effective thermal conductivity of food samples was dependent on the concentration of solute. The value decreased with an increase in the concentration of solutes at both frozen and unfrozen states. For frozen state, thermal conductivity was strongly dependent on emperature reflecting the change in the fraction of frozen water with emperature. The fraction of frozen water of food sample obtained showed a good consisiency with theoretical prediction based on the phase diagram data. The intrinsic thermal conductivities of solids were determined from the effective thermal conductivity obtained from untrozen state and structure models (series, parallel and untrozen state and structure models (series, parallel and MaxwellEucken). In frozen state, the prediction of effective thermal conductivity rom Maxwell-Eucken showed the best results among the three model

2Rp14ハイオリアクターによる大至タンバク吕の醂分解及ひ 生成物の梌討 ○李 華揚、益 敬、村本 光二、山内 文男

（東北大、応生化）

[目的］我々はバイオリアクターを用いて大豆タンバク界を醇素 分解することによりアミノ酸・ペブチド成分在得る研究存行ってき た。分解物を直品素村として利用する㧹合、従来の分解法でげル

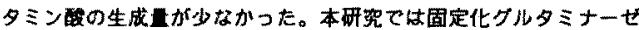
表利用して、ハイオリアクターによるグルタミン酸の生成について 柣討を行つた。

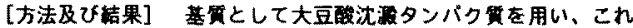

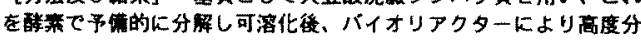

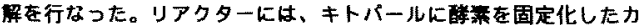

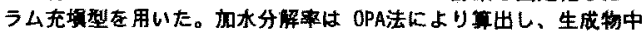
のアミノ酸についてはアミノ酸分析をして出校模即を行った。基算

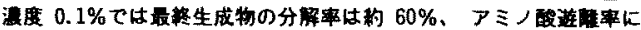
して衫 $50 \%$ てあった。さらにこの分睤物について固定化グルタミ ナーゼを利用するバイオリアクターにより、グタミンからグルタ ミン酸への夜換を行ったところ生成青が良来仁比へて增加した。ま

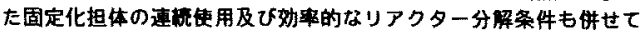
馀討を行った。

\section{Rp15固定化ブロテアーゼによる魚肉タンバつの加水分解

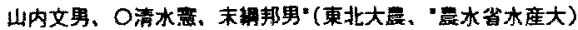

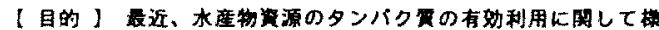
タな研究がはされており、本研究で、これらのタンバク貫を加 办分解し、ベブチドやアミノ能にまて低分子化し、利用策围広

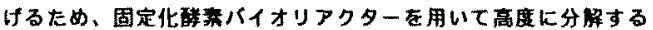
ための条件を莄討した。また、楞昧料としての利用を考蜼に入ん 呈昧性についての聥詰も行った。

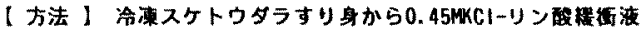

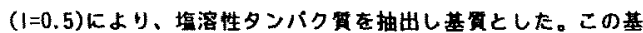

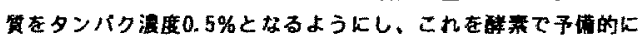

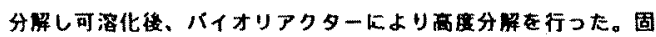
定化担体はキトバールを使用し、グルタルアルテヒドによる架掩 法により磷素固定化した。パイオリアクターにはカラム老场型 およひ回枟カラム型りアクターを情用した。

【結果】24時间後の分哓速 50\%以上となり、かなり低分子化

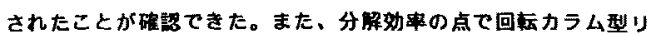
アクターのカが儌れていることが破できた。 
2Rp 16

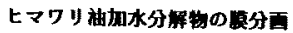

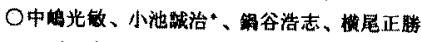

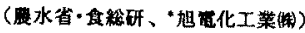

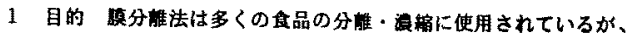

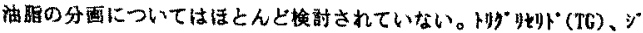

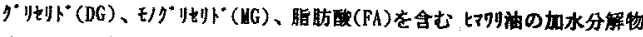

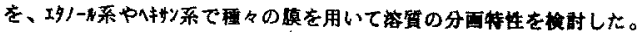

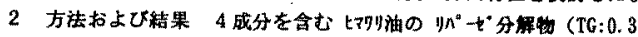

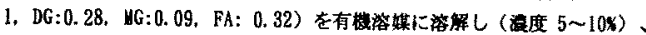

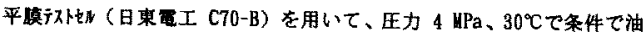

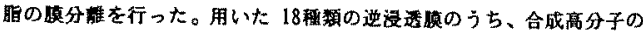

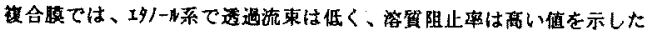

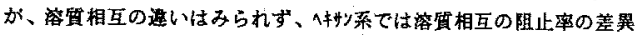
が若干みられたが、全体として低く、透遇流束も低加った。19/ー系て、

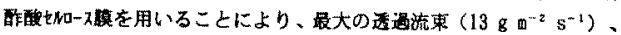
4 成分の阻止率 (TG:99\%、DG:93X，四:60\%，FA:57x) の值加得られた。

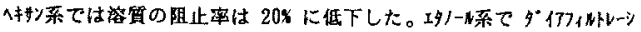

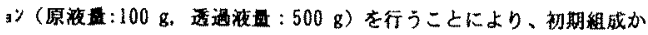
ら (TG:0.65，DG:0.30. HG:0.02. FA:0.04)にまで変えること汃でた。

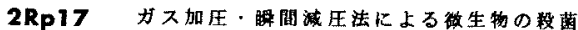

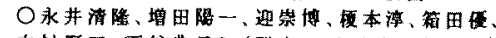
中墇三、天谷典子*䬺大・エ、*サントリー)

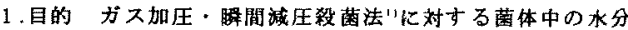

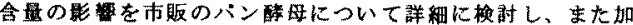
熱耓菌法に対して耐性を示す胞子八の闹法の店用を試みた。

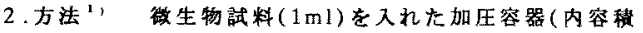
$40 \mathrm{ml})$ を設定圧力下、設定接触時閒CO2ガスにより加 压した後、容器内のガスを急速に大铞中に放出した。減 圧はその時定数が2.73、0.106[1/sec] となる 2 程類 の方法により試みた。水分含量の影䀧はS.cerevisiaeを、

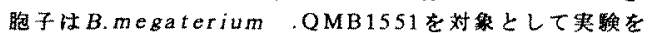
行い、処理融料は前者に对しては生菌敦を、後者として はさらに発茅率、発茅活性化率志测定し評価した。生菌

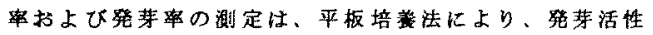

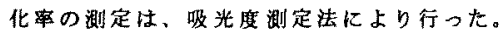

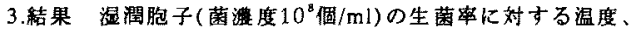

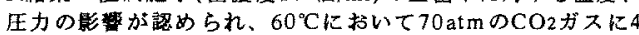

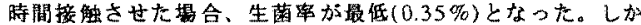
し、発芽事には影新が認められす、発芽活性化事は、温度上 异に伴亏生菌率の低下とともに低くなった。

1)中村厚三ら,苌芸化学会就, 66(3),282(1992)

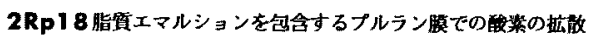

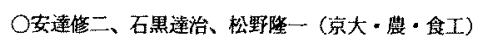

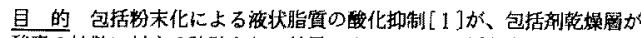
酸素の拡散に対する障壁となる好果のみによるのか否かを明らかにする

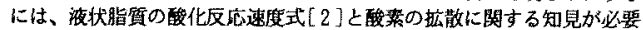

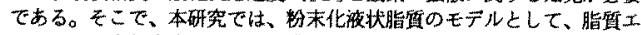

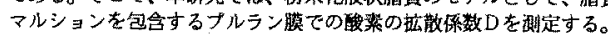
方法 オレイン酸メチルを界面活性群（Tween 20またはレシチン） 含む水溶液とともにホモジナイザでエマルション化した。これを淔心分

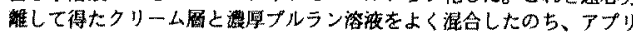
ケータを用いて裂膜した（法A）。また、上部のエマルションを酸 セルロース膜を通して柆锋が小さく分布の喇いエマルションを調政し、

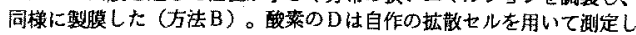
t $[3]$ 。

結 果 脂筫エマルションを包含した膜での酸紫のDは、包含しない㷎 合に此へて大きくなった。方法Aのりは並列モデルによる値に近かった。 また、方法BのDは方法AのDに比へて小さかった。これらのD在説明

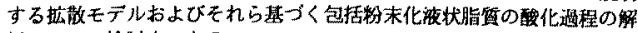
析について检討中である。

1) J. Imagi et al.: Biosci. Biotech. Biochen, 56, 1236 (1992).

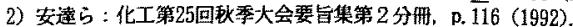

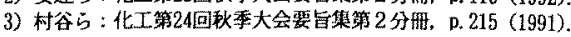

2Rp19 ヒーカラギーナンのソルーゲル転移点近傍におけるゲルの弾 性率密化

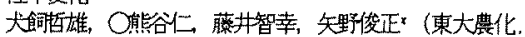
現・横㙃国大物筫工

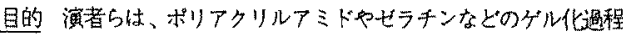
へのバーコレーション理輪の適用を試みてきた1)。今回は、多糖類 の る相関跑蜼則定から決定し、をれを用いて転移点近傍におけるゲ の弾性率のパーコレーション理羭による解析を行った。

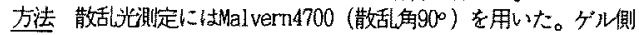
の動的ずり弾生率測定には、レオログラフゾル(菓洋精譏、測定圊 波数 2Hz）を使用した。動的光散乱法により求められだ゙ル化点を 用いて、前報と同梯にして、ダルの弹性率の臨界指数 $\mathrm{t}$ を算出した。

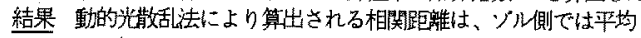

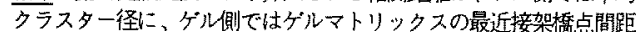
剩に相当すると考えられているが、いずれもソルーゲル軾移点近榜 において登散する傾回わ覞られ、ゲル化点濃度、ゲル化点温度が算 出された。臨界指数 t は、弾性率の濃度依存性、温度依存性いず

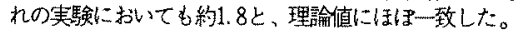

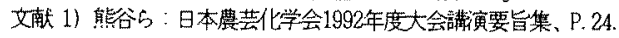

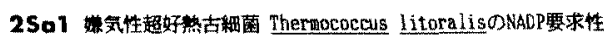

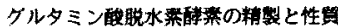
西田震一、武田朋子、O大島短久(京数大・理学)

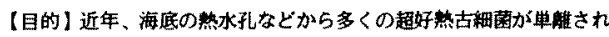

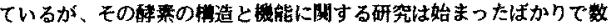

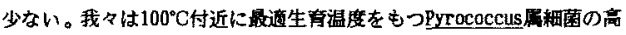

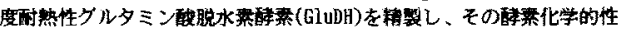

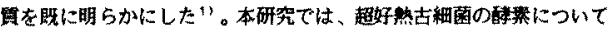

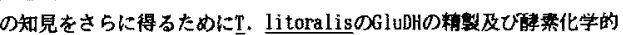

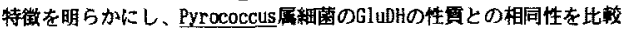
模誩した。

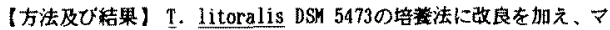

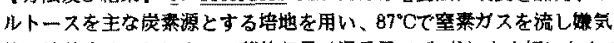
的に培することによって菌体収量（湿重量: $1.5 \mathrm{~g} / 1$ ) を大幅に向上で

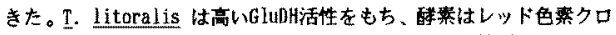

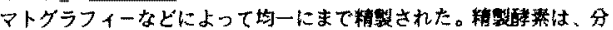
子量300kDaで、6量体揞造を有していること、L-Gluに高い特異性を示

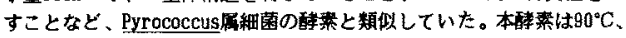

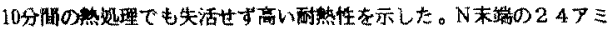

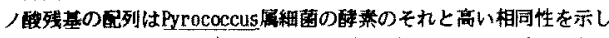
太。文献:1) T. Ohshiva \& N. Nishida(1992)International Conference, Therwophiles: Science and Technology, Abstract p.36.

$2 S a 2$ 嗑度好熱性古細菌Thermococcus sp. DT5432の生座 するグルタミン酸脱水妻酝素の精製と栍算

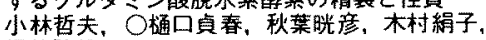
掘越弘毅

(理研・微生物，立教大·理，海洋科技セ，東工大)

Thermococcus sp. DT5432は。吱高生育温度を90'Cに持

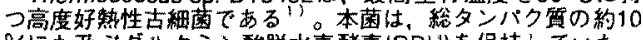
\%にも及ぶグルタミン酸脱水素酔(GDH)を保持していた。 我々は、このGDHの役割を明かにするため，本酷素の精製及 び諸性暂の検討を行なった。

DEAE-TOYOPEARL 650M, Matrex gel Red A, Mono $Q$ 及 $U^{*}$ superoseのカラムクロマトグラフィーにより本醭を電第泳 動的に単一なタンパク留として精製した。本酳秦は，サブユ

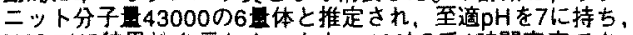

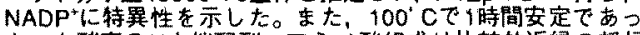

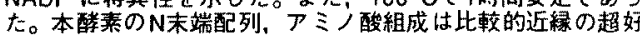
势性古縕菌Pyrococcus のGDHと高い相同性を示した。2-才 キソグルタル酸に対する本 GDHOKm值は $0.2 \mathrm{mM}$ と低いのに 比較して、グルタミン酸に対する $\mathrm{Km}$ 値は7mMと非常に高い。 さらに，本菌においては，变等代謝のkey enzymeであるグル タミン酸合成醉案の活性が現在のところ梌出されず，また菌 体内に多吾のGDHが存在する。以上の事実から、本菌におけ る $\mathrm{NH}_{3}$ の同化はGDHによると考えられる。

1)小林，掘越 1992年度鞋演要旨集 p 273 